\title{
Hypoxia induces autophagy in cardiomyocytes via a hypoxia-inducible factor 1-dependent mechanism
}

\author{
$\mathrm{LAN} \mathrm{GUI}^{1,2^{*}}$, BATU LIU ${ }^{3 *}$ and GUANG LV \\ ${ }^{1}$ Department of Basic Theory, Sports Institute of Inner Mongolia University for the Nationalities; \\ ${ }^{2}$ Institute of Mongolian Genome and Genetic Diseases, Inner Mongolia University for the Nationalities; \\ ${ }^{3}$ Sports Department, Sports Institute of Inner Mongolia University for the Nationalities; \\ ${ }^{4}$ Institute of Pathogenic Microbiology and Immunology, Inner Mongolia University for the Nationalities, \\ Tongliao, Inner Mongolia 028041, P.R. China
}

Received October 21, 2014; Accepted August 26, 2015

DOI: $10.3892 /$ etm.2016.3190

\begin{abstract}
Hypoxia frequently accompanies such vascular disorders as atherosclerosis, thrombosis and ischemia/reperfusion injury. Myocardial ischemia/reperfusion, in particular, is a major contributor to cardiomyocyte impairment. Autophagy is a dynamic, self-catabolic process that has been implicated in a wide range of physiological processes and the pathogenesis of diverse diseases. The aim of the present study was to investigate the promotion of autophagy by hypoxia in a rat $\mathrm{H} 9 \mathrm{c} 2$ heart cell line and determine the regulatory role of hypoxia-inducible factor 1 (HIF-1) in the hypoxia-induced autophagy in H9c2 cells, using quantitative green fluorescent protein-microtubule-associated protein 1 light chain 3 analysis and electron microscopy of autophagic vesicles. In addition, western blot and quantitative polymerase chain reaction analysis of autophagy-associated markers was conducted. In addition, the role of HIF-1-mediated autophagy in the hypoxia-induced impairment of $\mathrm{H} 9 \mathrm{c} 2$ cells was examined, as a measure of cellular viability, using an MTT assay. The results demonstrated that autophagy was induced in $\mathrm{H} 9 \mathrm{c} 2$ cells under hypoxia, and the autophagy induction triggered by hypoxia could be enhanced by HIF-1 $\alpha$ overexpression and inhibited by HIF-1 $\alpha$ knockdown. Furthermore, the HIF-1-mediated autophagy ameliorated the reduction in the $\mathrm{H} 9 \mathrm{c} 2$ cell viability induced by hypoxia. These findings provide a novel insight into the hypoxic-ischemic injury to cardiomyocytes and give
\end{abstract}

Correspondence to: Dr Lan Gui, Department of Basic Theory, Sports Institute of Inner Mongolia University for the Nationalities, 996 Xilamulun (West), Tongliao, Inner Mongolia 028041, P.R. China E-mail: languiimun@163.com

\section{${ }^{*}$ Contributed equally}

Key words: hypoxia, autophagy, hypoxia-inducible factor $1 \alpha$, cardiomyocytes evidence for the occurrence of HIF-1-mediated autophagy in myocardial ischemia.

\section{Introduction}

Hypoxia frequently accompanies such vascular disorders as atherosclerosis (1), thrombosis (2) and ischemia/reperfusion (I/R) injury (3). Myocardial ischemia/reperfusion, in particular, is a major contributor to cardiomyocyte impairment $(4,5)$. As the most prevalent disease afflicting humans $(6,7)$, coronary artery disease is mainly caused by the hypoxic-ischemic injury to cardiomyocytes $(8,9)$. Myocardial ischemia and infarction develop when the blood supply to the myocardium decreases or is discontinued. The mechanism underlying myocardial ischemia and infarction has yet to be fully elucidated; however, the oxygen deprivation, i.e. hypoxia, in myocardial ischemia and infarction can, to varying degrees, threaten the function and survival of cardiomyocytes $(10,11)$, although numerous adaptive countermeasures can be induced in the cardiomyocytes in response to the hypoxic condition (12-14).

Hypoxia-inducible factor 1 (HIF-1) is a transcription factor that functions as a master regulator of adaptive responses to reduced $\mathrm{O}_{2}$ environments (10). HIF-1 can improve local microcirculation, via effects on vascular growth and function, and regulate $\mathrm{O}_{2}$ utilization, by switching oxidative metabolism to glycolytic metabolism (15-17). HIF-1 is composed of HIF-1 $\alpha$ and HIF-1 $\beta$ subunits (18). HIF- $1 \alpha$, rather than HIF-1 $\beta$, is the $\mathrm{O}_{2}$-regulated subunit during hypoxia (19). Hypoxia and re-oxygenation potently increase HIF-1 transcriptional activity and HIF-1 $\alpha$ protein levels (20-22). Upregulated HIF-1 $\alpha$ activation has been demonstrated in human hearts under conditions of myocardial ischemia and infarction (23) and in patients with coronary artery disease $(24,25)$.

Autophagy is a dynamic catabolic process that involves the delivery of cellular components to the lysosome for degradation. Autophagy has been implicated in a wide range of physiological processes and in the pathogenesis of diverse diseases $(26,27)$. In addition to its established roles in the maintenance of homeostasis and adaptation to stress, autophagy is involved in cell differentiation (28-30). Autophagy is a closely 
regulated process that helps to balance the synthesis, degradation and subsequent recycling of cellular products; however, little is known about the role of hypoxia-induced autophagy in hypertension and coronary artery disease, particularly in cardiomyocytes under hypoxia.

The aim of the present study was to investigate the autophagy in cardiomyocytes under hypoxia and evaluate the regulation of HIF-1 $\alpha$ in hypoxia-induced autophagy, as well as to examine the role of autophagy in cell viability.

\section{Materials and methods}

Reagents and cell culture. Rapamycin was purchased from Sigma-Aldrich (St. Louis, MO, USA). The coding sequence of the fusion of microtubule-associated protein 1 light chain 3 (LC3) with green fluorescent protein (GFP) was synthesized and cloned into pcDNA3.1(+) (Invitrogen Life Technologies, Carlsbad, CA, USA) to construct the LC3-GFP-expressing plasmid. The coding sequence of HIF-1 $\alpha$ was synthesized and cloned into pcDNA3.1(+) to construct the HIF-1 $\alpha$-pcDNA3.1(+)-expressing plasmid. The HIF-1 $\alpha$ small interfering RNA (siRNA) sequence was designed and the duplexes were produced by Shanghai GenePharma Co., Ltd. (Shanghai, China).

A rat $\mathrm{H} 9 \mathrm{c} 2$ heart cell line was purchased from the American Type Culture Collection (Manassas, VA, USA), cultured in Dulbecco's modified Eagle's medium (DMEM; Invitrogen Life Technologies) supplemented with $10 \%$ fetal bovine serum (FBS; Gibco-BRL, Grand Island, NY, USA), $100 \mathrm{U} / \mathrm{ml}$ penicillin (Shijiazhuang Pharmaceutical Group, Shijiazhuang, China) and $100 \mathrm{mg} / \mathrm{ml}$ streptomycin (Shijiazhuang Pharmaceutical Group), and grown in an atmosphere of $5 \% \mathrm{CO}_{2} / 95 \%$ humidified air at $37^{\circ} \mathrm{C}$. The culture medium was changed every second day.

Quantitative GFP-LC3 analysis and electron microscopy. Quantitative GFP-LC3 light microscopy autophagy assays were performed in $\mathrm{H} 9 \mathrm{c} 2$ cells following various treatments. The H9c2 cells grown to $80 \%$ confluence were transfected with a GFP-LC3-expressing plasmid using Lipofectamine ${ }^{\circledR} 2000$ (Invitrogen Life Technologies). After transfection for $24 \mathrm{~h}$, the cells were subjected to rapamycin treatment $(200 \mathrm{nM})$ (Sigma-Aldrich) for another $24 \mathrm{~h}$ or were pretreated with hypoxia for $2 \mathrm{~h}$ and analyzed using fluorescence microscopy. In another experiment, the GFP-LC3-expressing plasmid transfection was followed by the transfection of the $\mathrm{H} 9 \mathrm{c} 2$ cells with HIF-1 $\alpha$-pcDNA3.1(+), pcDNA3.1(+) or HIF-1 $\alpha$ siRNA; $24 \mathrm{~h}$ later, the cells were analyzed using fluorescence microscopy.

RNA isolation and reverse transcription quantitative polymerase chain reaction analysis ( $R T-q P C R)$. Total cellular RNA from $2-5 \times 10^{5}$ cells was prepared with TRIzol reagent (Thermo Fisher Scientific, Inc., Waltham, MA, USA), and reverse transcription (RT) was performed using Moloney Murine Leukemia Virus Reverse Transcriptase (Promega Corp., Madison, WI, USA). Primer sequences are as follows: are as following: Beclin 1, F 5'-TGAAAATGAGTGTCA GAACT-3' and R 5'-CTGTTCACTGTCATCCTCAT-3'; autophagy-related gene 5 (Atg5), F 5'-TATCAGAGCATG
TCACCCTT-3' and R 5'-TTCCTGTCTGGCTTGCAGCA-3'); Atg7, F 5'-GTCCAAGTTCCAGTGGCTGT-3' and R 5'-CTC GGGCCCTGCACCTGTGC-3'; and $\beta$-actin, F 5'-TGTCCA CCTTCCAGCAGATGT-3' and R 5'-AGCTCAGTAACAGTC CGCCTAGA-3'. PCR cycling conditions were as follows: $42^{\circ} \mathrm{C}$ for $10 \mathrm{~min}$ and $95^{\circ} \mathrm{C}$ for $20 \mathrm{sec}$ for the reverse transcription, and $95^{\circ} \mathrm{C}$ for $10 \mathrm{sec}$ and $60^{\circ} \mathrm{C}$ for $30 \mathrm{sec}$ for the PCR reaction, repeated for 35 cycles. For the quantitative analysis of the mRNA expression of Beclin 1, autophagy-related gene 5 (Atg5) and Atg7, qPCR was conducted using a LightCycler ${ }^{\circledR} 480$ system (Roche Diagnostics GmbH, Mannheim, Germany); $1 \mu \mathrm{g}$ RNA per sample was converted to cDNA and used for qPCR. Data were normalized based on $\beta$-actin, using the $2^{-\Delta \Delta \mathrm{Cq}}$ method.

Western blot assay. Polyclonal antibodies for $\beta$-actin (A2066; 1:1,000) and LC3-I/LC3-II (L8918, 1:600) were purchased from Sigma-Aldrich. The Beclin 1 polyclonal antibody was purchased from Santa Cruz Biotechnology, Inc. (sc-48341; 1:500, Santa Cruz, CA, USA), and the Atg5 (cat. no. 2630; 1:600) and Atg7 (cat. no. 2631; 1:600) monoclonal antibodies were purchased from Cell Signaling Technology, Inc. (Danvers, MA USA). Cell extracts were prepared by a standard protocol using Cell Lysis Buffer (Cell Signaling Technology, Inc.), and protein levels were quantified using a Bio-Rad protein assay (Bio-Rad Laboratories, Inc., Hercules, CA, USA). Samples were separated using $10 \%$ SDS-PAGE electrophoresis and transferred to a PVDF membranes (EMD Millipore, Billerica, MA, USA). After blocking with 3\% bovine serum albumin (Ameresco, Inc., Framingham, MA, USA) overnight at $4^{\circ} \mathrm{C}$, the membrane was incubated overnight again at $4^{\circ} \mathrm{C}$ with anti-Beclin 1, anti-Atg5, anti-Atg7, anti-LC3-II or anti- $\beta$-actin antibody. Goat anti-mouse IgG or goat anti-rabbit IgG (Pierce Biotechnology, Inc., Rockford, IL, USA) secondary antibodies conjugated to horseradish peroxidase and enhanced chemiluminescence detection systems (GE Healthcare Life Sciences, Little Chalfont, UK) were used for detection.

Cell viability assay. Cell viability was determined using an MTT assay (Thermo Fisher Scientific, Inc.). The H9c2 cells were seeded in 96-well plates; after $24 \mathrm{~h}$, the medium was replaced with DMEM containing 2\% FBS. At $24 \mathrm{~h}$ after the treatment, the incubation medium in the test wells was replaced with $50 \mu \mathrm{l} 1 \mathrm{X}$ MTT solution, and the cells were incubated for $2 \mathrm{~h}$ at $37^{\circ} \mathrm{C}$. Following incubation, the MTT solution was discarded, and $150 \mu \mathrm{l}$ dimethylsulfoxide (DMSO) was added to dissolve the precipitate completely at room temperature. The optical density was then measured at $570 \mathrm{~nm}$ using a spectrophotometer. The cell viability was expressed as relative viable cells (\%) to control $\mathrm{H} 9 \mathrm{c} 2$ cells. All experiments were performed in three separate experiments.

Statistical analysis. For GFP-LC3 dot number analysis, relative mRNA expression of Beclin 1, Atg5 and Atg7 to $\beta$-actin, and MTT measurements, data are presented as the mean \pm standard error. Data were analyzed by Student's t-test using GraphPad Prism 5 (GraphPad Software, Inc., La Jolla, CA, USA), and $\mathrm{P}<0.05$ was considered to indicate a statistically significant difference. 

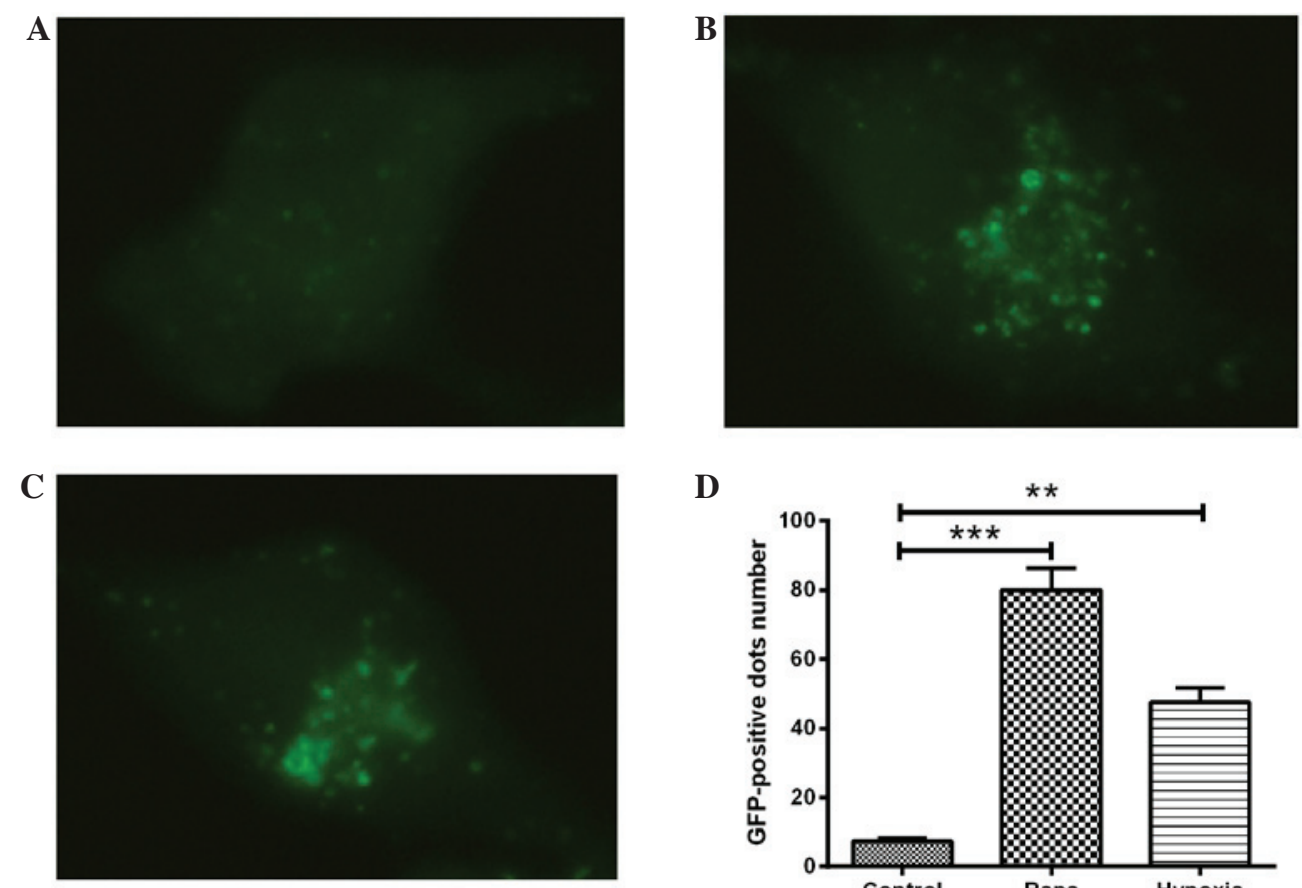

D

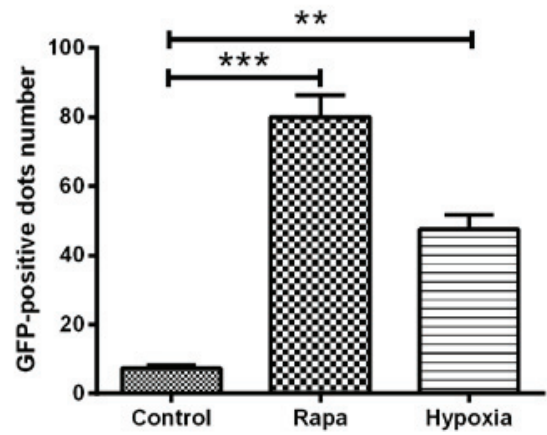

Figure 1. Hypoxia induces autophagy in cardiomyocytes. (A-C) The cardiomyocytes were transfected with a plasmid that expressed a GFP-LC3 fusion protein. After $24 \mathrm{~h}$, the cells were incubated for another $24 \mathrm{~h}$ at $37^{\circ} \mathrm{C}$ in Dulbecco's modified Eagle's medium with (A) dimethylsulfoxide (1:10,000 dilution) (control), (B) $100 \mathrm{nM}$ rapamycin or $(\mathrm{C})$ under hypoxia $\left(1 \% \mathrm{O}_{2}\right)$. Following fixation, the cells were immediately visualized using fluorescence microscopy. (D) The number of punctate GFP-LC3 dots in each cell was counted, and $\geq 100$ cells were included for each group. The data were normally distributed and were statistically analyzed using the Student's t-test. ${ }^{* * *} \mathrm{P}<0.01$ and ${ }^{* * * *} \mathrm{P}<0.001$ vs. control. Experiments were independently performed in triplicate. GFP, green fluorescent protein; LC3, microtubule-associated protein 1 light chain 3; rapa, rapamycin.

A

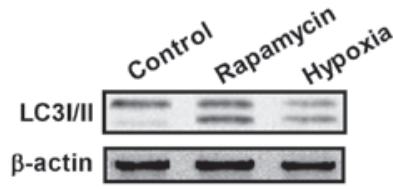

B

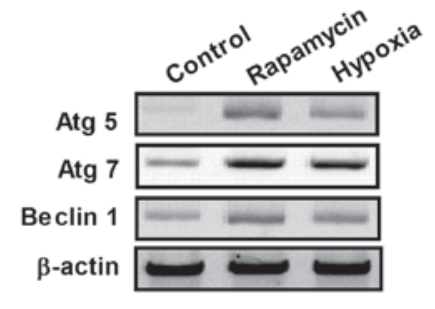

\section{C}

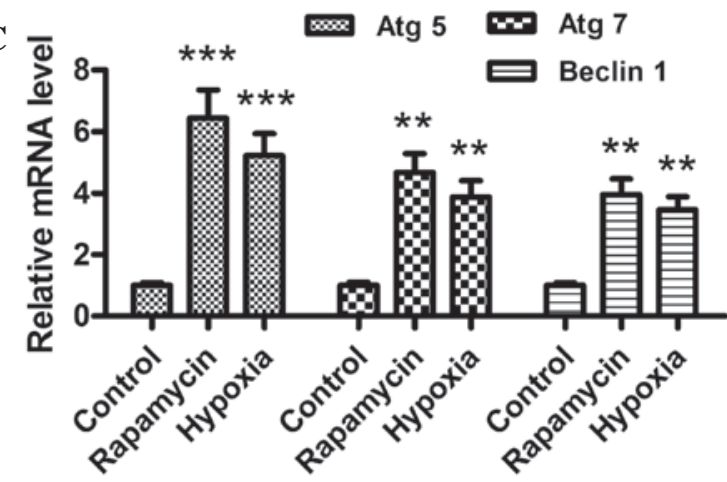

Figure 2. Hypoxia promotes the conversion of LC3-I to LC3-II and upregulates the expression of Atg5, Atg7 and Beclin 1 in cardiocmyocytes. (A and B) Western blot assay of LC3-I/-II, Atg5, Atg7 and Beclin 1 in H9c2 cells following rapamycin or hypoxia treatment for $24 \mathrm{~h}$. After the treatment with dimethylsulfoxide (1:10,000 dilution), $100 \mathrm{nM}$ rapamycin or hypoxia $\left(1 \% \mathrm{O}_{2}\right)$, the cells were lysed and subjected to western blotting with antibodies against LC3-I/-II, Atg5, Atg7 or Beclin 1. (C) mRNA levels of Atg5, Atg7 and Beclin 1 in cardiomyocytes, $24 \mathrm{~h}$ after treatment with $100 \mathrm{nM}$ rapamycin or hypoxia $\left(1 \% \mathrm{O}_{2}\right)$. The total cell mRNA was analyzed using a reverse transcription quantitative polymerase chain reaction. ${ }^{* * *} \mathrm{P}<0.01$ and ${ }^{* * * *} \mathrm{P}<0.001$ vs. control. All results were independently repeated three times. LC3, microtubule-associated protein 1 light chain 3; Atg, autophagy-related gene.

\section{Results}

Hypoxia induces autophagy and the expression of autophagy-associated molecules in H9c2 cells. H9c2 cells were transfected with GFP-LC3, a biomarker for autophagy, and exposed to hypoxic conditions for $24 \mathrm{~h}$. LC3, which comprises the two isoforms LC3-I and LC3-II, typically exhibits diffuse cytosolic distribution. Representative fluorescence images, shown in Fig. 1A-C, indicated that, compared with the DMSO control treatment (Fig. 1A), treatment with rapamycin (Fig. 1B) or hypoxia $\left(1 \% \mathrm{O}_{2}\right)$ (Fig. 1C) led to the redistribution of LC3 to punctuate structures and significantly increased the number of LC3-GFP-positive vesicles in the H9c2 cells ( $\mathrm{P}<0.001$ or $\mathrm{P}<0.01$; Fig. 1D). The ultrastructures of the H9c2 cells with hypoxia or with rapamycin treatment were observed using electron microscopy, and prominent features of cells with hypoxia or rapamycin treatment were found in the form of autophagic vacuoles and autolysosomes in the cytoplasm (data not shown).

When autophagy is activated, the LC3-I protein localized in the cytoplasm is cleaved, converted into LC3-II and inserted into autophagosome membranes (31). To detect the expression 

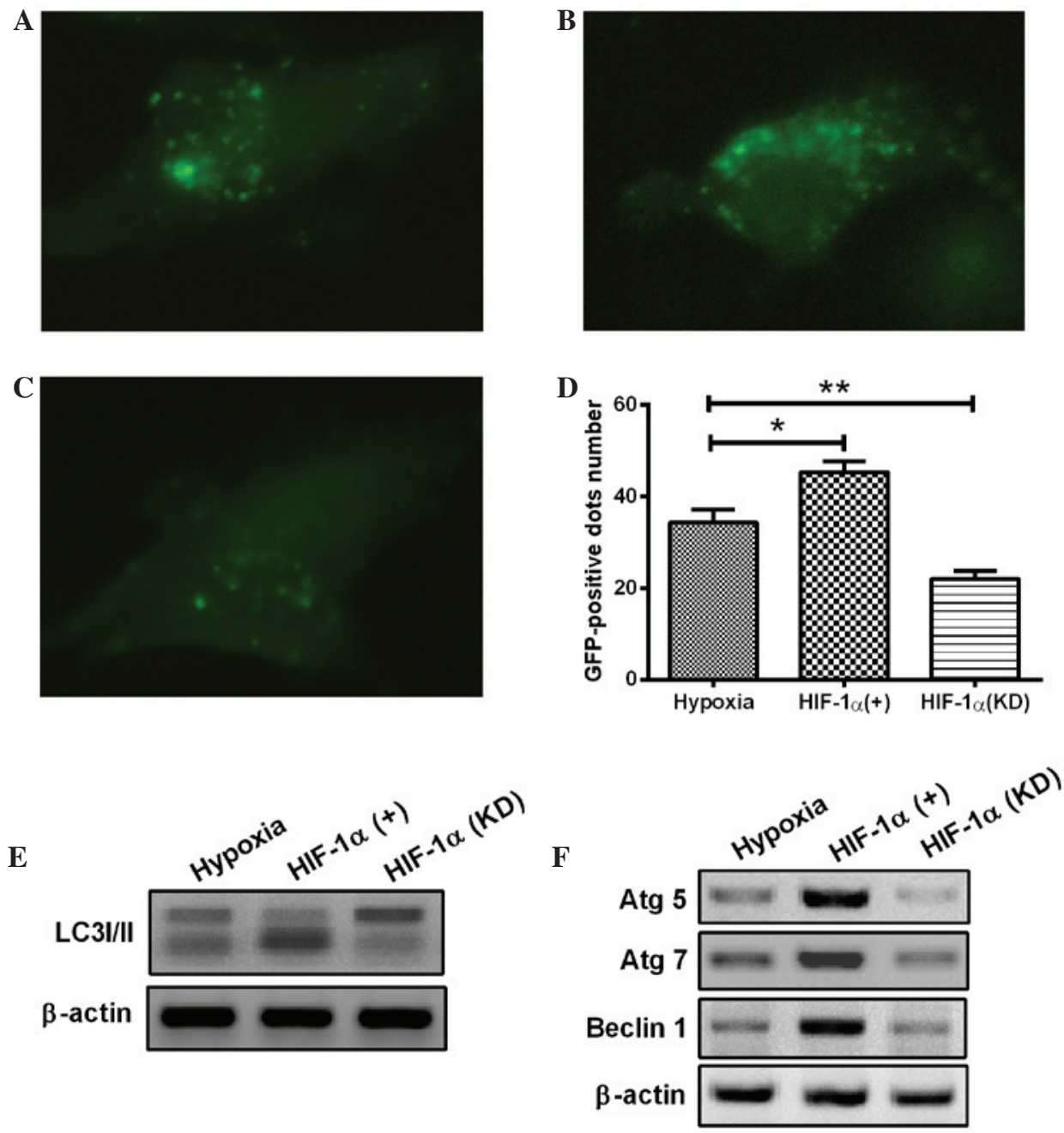

Figure 3. Hypoxia induces autophagy in cardiomyocytes through the HIF-1 $\alpha$ pathway. (A-D) The cardiomyocytes were transfected with a plasmid that expressed a GFP-LC3 fusion protein and (A) pcDNA3.1, (B) pcDNA-HIF-1 $\alpha$ or (C) HIF-1 $\alpha$ siRNA. At $24 \mathrm{~h}$ after transfection, the cells were cultured under hypoxia $\left(1 \% \mathrm{O}_{2}\right)$ for a further $24 \mathrm{~h}$. Following fixation, cells were immediately visualized using fluorescence microscopy. (D) The number of punctate GFP-LC3 dots in each cell was counted, and $\geq 100$ cells were included for each group. ${ }^{*} \mathrm{P}<0.05$ and ${ }^{* *} \mathrm{P}<0.01$ vs. hypoxia. ( $\mathrm{E}$ and $\left.\mathrm{F}\right)$ Following transfection with pcDNA-HIF-1 $\alpha$ or HIF-1 $\alpha$ siRNA for $24 \mathrm{~h}$, the cells were lysed and subjected to western blotting with the antibodies indicated. All results are averaged for three independent experiments. HIF-1 $\alpha$, hypoxia-inducible factor $1 \alpha$; GFP, green fluorescent protein; LC3, microtubule-associated protein 1 light chain 3; siRNA, small interfering RNA; Atg, autophagy-related gene.

of LC3-II, western blotting was performed with the lysates from $\mathrm{H} 9 \mathrm{c} 2$ cells subjected to hypoxia $\left(1 \% \mathrm{O}_{2}\right)$ or rapamycin treatment (Fig. 2A). As part of a type III phosphoinositide-3 kinase complex, the autophagy gene Beclin 1 is required for the formation of the autophagic vesicles (32). In addition, ATG products, such as Atg5 and Atg7, play essential roles in autophagy. As shown in Fig. $2 \mathrm{~B}$ and $\mathrm{C}$, the mRNA and protein expression levels of Atg5, Atg7 and Beclin 1 increased following hypoxia or rapamycin treatment. Notably, these results indicate that hypoxia and rapamycin treatment induce autophagy in $\mathrm{H} 9 \mathrm{c} 2$ cells.

Hypoxia-induced autophagy-related molecules are regulated by HIF-1 in H9c2 cells. To reveal the precise mechanisms underlying the activation of autophagy in $\mathrm{H} 9 \mathrm{c} 2$ cells, the change in HIF-1 $\alpha$ expression was further investigated with a pcDNA3.1 eukaryotic plasmid and chemically synthesized siRNA. HIF-1, as a key transcription factor, plays a pivotal role in hypoxia. The HIF-1 overexpression with eukaryotic plasmid or HIF-1 knockdown with siRNA was induced in the
H9c2 cells. As shown in Fig. 3A-D, overexpression of HIF-1 significantly enhanced the occurrence of hypoxia-induced autophagy (Fig. 3B), whereas the HIF-1 knockdown attenuated the hypoxia-induced formation of autophagic vacuoles in H9c2 cells (Fig. 3C), compared with the control H9c2 cells under hypoxia $\left(1 \% \mathrm{O}_{2}\right)$. Furthermore, HIF-1 overexpression markedly aggravated the transformation of LC3-I to LC3-II (Fig. 3E) and significantly promoted the expression of Atg5, Atg7 and Beclin 1 (Fig. 3F). By contrast, transfection with HIF-1 siRNA, which blocked HIF-1 expression, significantly prevented LC3-II production, as well as the expression of Atg5, Atg7 and Beclin 1 (Fig. 3E and F). The results therefore showed that the hypoxia-induced autophagy in H9c2 cells was dependent on HIF-1 $\alpha$. In combination, the results suggest that the HIF-1 pathway regulates the activation of autophagy in $\mathrm{H} 9 \mathrm{c} 2$ cells under the hypoxic condition.

HIF-1 $\alpha$-mediated autophagy attenuates the hypoxia-induced reduction in $\mathrm{H} 9 \mathrm{c} 2$ cell viability. The initial experiments demonstrated that HIF-1 induced significant autophagy and 
A

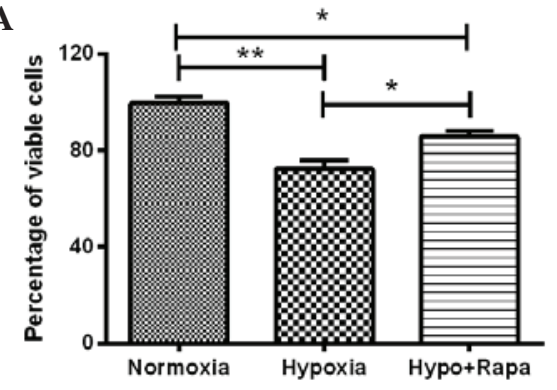

B

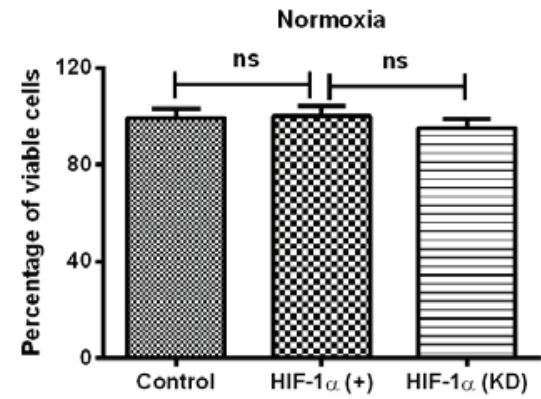

C

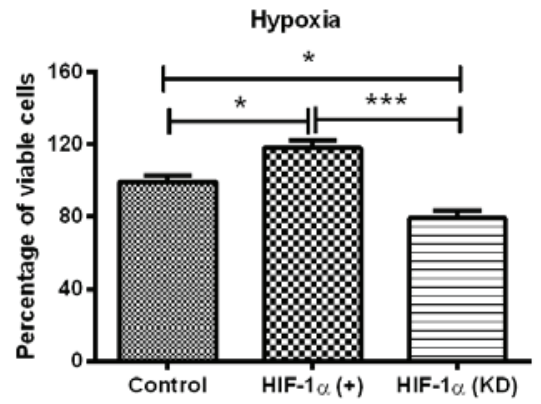

Figure 4. Viability of H9c2 cells under hypoxia or following HIF-1 $\alpha$ expression regulation. (A) Viability of H9c2 cells under normoxia, hypoxia or under hypoxia and following $200 \mathrm{nM}$ rapamycin treatment. (B and C) Viability of H9c2 cells following HIF-1 $\alpha$ overexpression or knockdown, (B) under normoxia or $(\mathrm{C})$ hypoxia. Normal H9c2 cells were taken as a control. All results are representative of four independent experiments. ${ }^{*} \mathrm{P}<0.05$, ${ }^{* *} \mathrm{P}<0.01$ and ${ }^{* * * *} \mathrm{P}<0.001$. HIF-1 $\alpha$, hypoxia-inducible factor $1 \alpha$; Hypo + Rapa, hypoxia and rapamycin treatment; ns, not significant; KD, knockdown.

high expression levels of autophagy-associated molecules in $\mathrm{H} 9 \mathrm{c} 2$ cells. To further determine the effect of HIF-1 $\alpha$-mediated autophagy under hypoxia on cell viability, the MTT assay was conducted for $\mathrm{H} 9 \mathrm{c} 2$ cells under several conditions: Hypoxia, normoxia, post-rapamycin treatment, HIF-1 $\alpha$ overexpression and HIF-1 $\alpha$ knockdown. It was shown that the viability of $\mathrm{H} 9 \mathrm{c} 2$ cells under hypoxia was significantly reduced compared with the viability of the cells under normoxia ( $\mathrm{P}<0.01$; Fig. $4 \mathrm{~A})$. Notably, the reduction in cell viability was reversed by the autophagy inducer rapamycin $(\mathrm{P}<0.05$; Fig. 4A). To further investigate the role of HIF-1 $\alpha$ in the hypoxia-induced cell viability reduction, the viability of $\mathrm{H} 9 \mathrm{c} 2$ cells was re-examined with HIF-1 $\alpha$ overexpression or knockdown. As shown in Fig. 4B, manipulation of the HIF-1 $\alpha$ level (overexpression or knockdown) under normoxia had no significant effect on the cell viability, whereas the upregulation and downregulation of HIF-1 $\alpha$ led to a significantly different effect on the viability of H9c2 cells under hypoxia, compared with the cells under hypoxia only. HIF-1 $\alpha$ overexpression significantly ameliorated the reduction in cell viability $(\mathrm{P}<0.05$; Fig. $4 \mathrm{C})$, whereas HIF-1 $\alpha$ knockdown enhanced the hypoxia-induced reduction in cell viability $(\mathrm{P}<0.05$; Fig. $4 \mathrm{C})$. The difference in cell viability between the cells with HIF-1 $\alpha$ upregulation and HIF-1 $\alpha$ downregulation was particularly significant $(\mathrm{P}<0.01$; Fig. 4C). In combination, these results suggest that HIF-1 $\alpha$-induced autophagy attenuates the hypoxia-reduced viability of $\mathrm{H} 9 \mathrm{c} 2$ cells.

\section{Discussion}

Hypoxia-induced cell death is a major concern in various clinical settings and plays a critical role in various physiopathological processes, such as hypoxic/ischemic disease, organ transplantation, angiogenesis or tumor invasion (33-35). I/R injury comprises a series of events that may occur together or separately: Reperfusion arrhythmias, myocardial stunning in 'reversible mechanical dysfunction', microvascular damage and cell death (36-38). Previous studies have demonstrated that autophagy is a lysosomal degradation process that occurs within the cell and has crucial physiological cellular functions, including the degradation of abnormally folded proteins, organelle turnover and adaptations to such stresses as nutrient depletion, acidic stress, oxidative stress and I/R injury (39-44). Furthermore, Macrophage autophagy has been indicated to play a protective role in advanced atherosclerosis in a mouse model (45); however, the protective role of autophagy in cardiomyocytes under hypoxia has not yet been elucidated.

In the present study, increased autophagic activity was detected in cardiomyocytes under hypoxia. To the best of our knowledge, this is the first study to report the effects of hypoxia on autophagy induction in cardiomyocytes. Several approaches were adopted to determine the levels of autophagy, including the analysis of fluorescent LC3-GFP dots and the mRNA and protein expression levels of autophagy-associated molecules. Cardiomyocytes were exposed to hypoxia, and an evident increase was found in the number of autophagic vacuoles and autolysosomes in the cytoplasm, suggesting enhanced autophagy formation. The occurrence of autophagy was also confirmed with rapamycin treatment in the H9c2 cell model. The analysis of autophagy-associated molecule levels confirmed the induction of autophagy by hypoxia or rapamycin: The expression of LC3-II increased in cells post-hypoxia or -rapamycin treatment, and the Beclin 1, Atg5 and Atg7 expression increased in cardiomyocytes post-hypoxia or -rapamycin treatment at both the mRNA and protein levels. In summary, autophagy could be induced by hypoxia in cardiomyocytes in vitro.

HIF-1 is a transcription factor that is essential in the regulation of gene expression to maintain oxygen homeostasis (46). HIF-1 has been demonstrated to coordinate adaptive responses to hypoxia at both the cellular and systemic levels $(18,47,48)$. Furthermore, HIF-1 has been shown to regulate the expression of hundreds of target genes involved in angiogenesis, erythropoiesis, metabolism, autophagy and other adaptive responses to hypoxia (49). To elucidate the mechanisms by which cardiomyocytes respond to hypoxia, an HIF-1 $\alpha$ overexpression plasmid and HIF- $1 \alpha$ siRNA were used to manipulate the HIF-1 $\alpha$ expression and to investigate the regulatory role of HIF-1 $\alpha$ in hypoxia-induced autophagy. The results demonstrated that the hypoxia-induced autophagy in cardiomyocytes involved the HIF-1 pathway. A significant increase in autophagy-specific autolysosomes was observed via the LC3-GFP reporter vector under a fluorescence microscope in HIF-1 $\alpha$-treated cells. By contrast, HIF-1 $\alpha$ knockdown with siRNA treatment led to considerably less autolysosome formation in the cardiomyocytes. Furthermore, the cleavage and recruitment of LC3 to autophagosomes, as well as the expression of autophagy-associated molecules, were enhanced by HIF-1 $\alpha$ overexpression 
and attenuated by HIF-1 $\alpha$ knockdown. In combination, these results indicated that the HIF-1 pathway was involved in hypoxia-induced autophagy in cardiomyocytes.

Hypoxia treatment and HIF-1 $\alpha$ overexpression were both found to induce autophagy; however, their effects on cell viability differed. Hypoxia appeared to reduce the cell viability, though accompanied by HIF-1 $\alpha$ stimulating, whereas HIF-1 $\alpha$ could significantly inhibit the reduction of cardiomyocyte viability. However, the overexpression of HIF-1 $\alpha$ ameliorated the reduction in cell viability induced by hypoxia, while the downregulation of HIF-1 $\alpha$ enhanced the hypoxia-induced cell viability reduction. The autophagy induced by HIF-1 may, therefore, facilitate cardiomyocytes to overcome the hypoxic injury and increase survival.

In conclusion, the results of the present study suggest that hypoxia can induce autophagy in cardiomyocytes through activation of the HIF-1 pathway. HIF-1 $\alpha$ upregulation can increase autophagy and ameliorate the hypoxia-induced cell viability reduction. The present study presents a promising foundation for the development of methods to prevent hypoxic-ischemic injury to cardiomyocytes.

\section{Acknowledgements}

The present study was supported by a grant from the Inner Mongolia Department of Education Project (no. NJZY13161(2013-2015).

\section{References}

1. Gautier-Veyret E, Arnaud C, Bäck M, Pépin JL, Petri MH, Baguet JP, Tamisier R, Lévy $P$ and Stanke-Labesque F: Intermittent hypoxia-activated cyclooxygenase pathway: Role in atherosclerosis. Eur Respir J 42: 404-413, 2013.

2. Bovill EG and van der Vliet A: Venous valvular stasis-associated hypoxia and thrombosis: What is the link? Annu Rev Physiol 73 527-545, 2011.

3. Matsushima S, Kuroda J, Ago T, Zhai P, Ikeda Y, Oka S, Fong GH, Tian R and Sadoshima J: Broad suppression of NADPH oxidase activity exacerbates ischemia/reperfusion injury through inadvertent downregulation of hypoxia-inducible factor-1 $\alpha$ and upregulation of peroxisome proliferator-activated receptor- $\alpha$. Circ Res 112: 1135-1149, 2013.

4. Talukder MA, Elnakish MT, Yang F, Nishijima Y, Alhaj MA, Velayutham M, Hassanain $\mathrm{HH}$ and Zweier JL: Cardiomyocyte-specific overexpression of an active form of Rac predisposes the heart to increased myocardial stunning and ischemia-reperfusion injury. Am J Physiol Heart Circ Physiol 304: H294-H302, 2013.

5. Goldhaber JI and Weiss JN: Oxygen free radicals and cardiac reperfusion abnormalities. Hypertension 20: 118-127, 1992.

6. Cheng TO: Coronary heart disease in China. Hosp Med 60: 456, 1999.

7. Barth J, Schneider S and von Känel R: Lack of social support in the etiology and the prognosis of coronary heart disease: A systematic review and meta-analysis. Psychosom Med 72: 229-238, 2010

8. Ostádal B: Myocardial ischemic injury and protection. Exp Clin Cardiol 9: 213-217, 2004.

9. Ost'ádal B, Ost'ádalova I, Skárka L, Kolár F and Kopecký J: Ischemic injury of the developing heart. Exp Clin Cardiol 7: 93-98, 2002.

10. Tong W, Xiong F, Li Y and Zhang L: Hypoxia inhibits cardiomyocyte proliferation in fetal rat hearts via upregulating TIMP-4. Am J Physiol Regul Integr Comp Physiol 304 R613-R620, 2013.

11. Botting KJ, McMillen IC, Forbes H, Nyengaard JR and Morrison JL: Chronic hypoxemia in late gestation decreases cardiomyocyte number but does not change expression of hypoxia-responsive genes. J Am Heart Assoc 3, 2014.
12. Ramjiawan A, Bagchi RA, Blant A, Albak L, Cavasin MA, Horn TR, McKinsey TA and Czubryt MP: Roles of histone deacetylation and AMP kinase in regulation of cardiomyocyte PGC-1 $\alpha$ gene expression in hypoxia. Am J Physiol Cell Physiol 304: C1064-C1072, 2013.

13. Muraguchi T, Kawawa A and Kubota S: Prohibitin protects against hypoxia-induced $\mathrm{H} 9 \mathrm{c} 2$ cardiomyocyte cell death. Biomed Res 31: 113-122, 2010.

14. Wang W, Peng Y, Wang Y, Zhao X and Yuan Z: Anti-apoptotic effect of heat shock protein 90 onhypoxia-mediated cardiomyocyte damage is mediated via the phosphatidylinositol 3-kinase/AKT pathway. Clin Exp Pharmacol Physiol 36: 899-903, 2009.

15. Shohet RV and Garcia JA: Keeping the engine primed: HIF factors as key regulators of cardiac metabolism and angiogenesis during ischemia. J Mol Med (Berl) 85: 1309-1315, 2007.

16. Taylor CT: Mitochondria and cellular oxygen sensing in the HIF pathway. Biochem J 409: 19-26, 2008.

17. Semenza GL: Hypoxia-inducible factor 1: Regulator of mitochondrial metabolism and mediator of ischemic preconditioning. Biochim Biophys Acta 1813: 1263-1268, 2011.

18. Wang GL, Jiang BH, Rue EA and Semenza GL: Hypoxia-inducible factor 1 is a basic-helix-loop-helix-PAS heterodimer regulated by cellular $\mathrm{O}_{2}$ tension. Proc Natl Acad Sci USA 92: 5510-5514, 1995.

19. SalcedaS andCaroJ:Hypoxia-induciblefactor lalpha(HIF-1alpha) protein is rapidly degraded by the ubiquitin-proteasome system under normoxic conditions. Its stabilization by hypoxia depends on redox-induced changes. J Biol Chem 272: 22642-22647, 1997.

20. Cai Z, Manalo DJ, Wei G, Rodriguez ER, Fox-Talbot K, Lu H, Zweier JL and Semenza GL: Hearts from rodents exposed to intermittent hypoxia or erythropoietin are protected against ischemia-reperfusion injury. Circulation 108: 79-85, 2003.

21. Yuan G, Nanduri J, Bhasker CR, Semenza GL and Prabhakar NR: $\mathrm{Ca}^{2+} /$ calmodulin kinase-dependent activation of hypoxia inducible factor 1 transcriptional activity in cells subjected to intermittent hypoxia. J Biol Chem 280: 4321-4328, 2005.

22. Yuan G, Nanduri J, Khan S, Semenza GL and Prabhakar NR: Induction of HIF-1alpha expression by intermittent hypoxia: Involvement of NADPH oxidase, $\mathrm{Ca}^{2+}$ signaling, prolyl hydroxylases and mTOR. J Cell Physiol 217: 674-685, 2008.

23. Lee SH, Wolf PL, Escudero R, Deutsch R, Jamieson SW and Thistlethwaite PA: Early expression of angiogenesis factors in acute myocardial ischemia and infarction. N Engl J Med 342: 626-633, 2000.

24. Hlatky MA, Quertermous T, Boothroyd DB, Priest JR, Glassford AJ, Myers RM, Fortmann SP, Iribarren C, Tabor HK, Assimes TL, et al: Polymorphisms in hypoxia inducible factor 1 and the initial clinical presentation of coronary disease. Am Heart J 154: 1035-1042, 2007.

25. Resar JR, Roguin A, Voner J, Nasir K, Hennebry TA, Miller JM, Ingersoll R, Kasch LM and Semenza GL: Hypoxia-inducible factor lalpha polymorphism and coronary collaterals in patients with ischemic heart disease. Chest 128: 787-791, 2005.

26. Shintani T and Klionsky DJ: Autophagy in health and disease: A double-edged sword. Science 306: 990-995, 2004.

27. Todde V, Veenhuis M and van der Klei IJ: Autophagy: Principles and significance in health and disease. Biochim Biophys Acta 1792: 3-13, 2009.

28. Kundu M, Lindsten T, Yang CY, Wu J, Zhao F, Zhang J, Selak MA, Ney PA and Thompson CB: Ulk1 plays a critical role in the autophagic clearance of mitochondria and ribosomes during reticulocyte maturation. Blood 112: 1493-1502, 2008.

29. Pua HH, Guo J, Komatsu M and He YW: Autophagy is essential for mitochondrial clearance in mature $\mathrm{T}$ lymphocytes. J Immunol 182: 4046-4055, 2009.

30. Srinivas V, Bohensky J and Shapiro IM: Autophagy: A new phase in the maturation of growth plate chondrocytes is regulated by HIF, mTOR and AMP kinase. Cells Tissues Organs 189: 88-92, 2009.

31. Wild P, McEwan DG and Dikic I: The LC3 interactome at a glance. J Cell Sci 127: 3-9, 2014.

32. Sun Y and Peng ZL: Programmed cell death and cancer. Postgrad Med J 85: 134-140, 2009.

33. Rayner BS, Duong TT, Myers SJ and Witting PK: Protective effect of a synthetic anti-oxidant on neuronal cell apoptosis resulting from experimental hypoxia re-oxygenation injury. J Neurochem 97: 211-221, 2006.

34. Hartel FV, Holl M, Arshad M, Aslam M, Gündüz D, Weyand M, Micoogullari M, Abdallah Y, Piper HM and Noll T: Transient hypoxia induces ERK-dependent anti-apoptotic cell survival in endothelial cells. Am J Physiol Cell Physiol 298: C1501-C1509, 2010. 
35. Bhogal RH, Weston CJ, Curbishley SM, Bhatt AN, Adams DH and Afford SC: Variable responses of small and large human hepatocytes to hypoxia and hypoxia/reoxygenation (H-R). Febs Lett 585: 935-941, 2011.

36. Hess ML, Barnhart GR, Crute S, Komwatana P, Krause S and Greenfield LJ: Mechanical and biochemical effects of transient myocardial ischemia. J Surg Res 26: 175-184, 1979.

37. Jeroudi MO, Hartley CJ and Bolli R: Myocardial reperfusion injury: Role of oxygen radicals and potential therapy with antioxidants. Am J Cardiol 73: 2B-7B, 1994.

38. Bolli R and Marbán E: Molecular and cellular mechanisms of myocardial stunning. Physiol Rev 79: 609-634, 1999.

39. Bartolome A, Guillen C and Benito M: Autophagy plays a protective role in endoplasmic reticulum stress-mediated pancreatic $\beta$ cell death. Autophagy 8: 1757-1768, 2012.

40. Zhang T, Qi Y, Liao M, Xu M, Bower KA, Frank JA, Shen HM, Luo J, Shi X and Chen G: Autophagy is a cell self-protective mechanism against arsenic-induced cell transformation. Toxicol Sci 130: 298-308, 2012.

41. Chen G, Ke Z, Xu M, Liao M, Wang X, Qi Y, Zhang T, Frank JA, Bower KA, Shi X and Luo J: Autophagy is a protective response to ethanol neurotoxicity. Autophagy 8: 1577-1589, 2012.

42. Marino ML, Pellegrini P, Di Lernia G, Djavaheri-Mergny M, Brnjic S, Zhang X, Hägg M, Linder S, Fais S, Codogno P and De Milito A: Autophagy is a protective mechanism for human melanoma cells under acidic stress. J Biol Chem 287: 30664-30676, 2012.
43. Wang D, Ma Y, Li Z, Kang K, Sun X, Pan S, Wang J, Pan H, Liu L, Liang D and Jiang H: The role of AKT1 and autophagy in the protective effect of hydrogen sulphide against hepatic ischemia/reperfusion injury in mice. Autophagy 8: 954-962, 2012.

44. Bhogal RH, Weston CJ, Curbishley SM, Adams DH and Afford SC: Autophagy: A cyto-protective mechanism which prevents primary human hepatocyte apoptosis during oxidative stress. Autophagy 8: 545-558, 2012.

45. Liao X, Sluimer JC, Wang Y, Subramanian M, Brown K, Pattison JS, Robbins J, Martinez J and Tabas I: Macrophage autophagy plays a protective role in advanced atherosclerosis. Cell Metab 15: 545-553, 2012.

46. Semenza GL: HIF-1 and mechanisms of hypoxia sensing. Curr Opin Cell Biol 13: 167-171, 2001

47. Iyer NV, Kotch LE, Agani F, Leung SW, Laughner E, Wenger RH, Gassmann M, Gearhart JD, Lawler AM, Yu AY and Semenza GL: Cellular and developmental control of $\mathrm{O}_{2}$ homeostasis by hypoxia-inducible factor 1 alpha. Genes Dev 12: 149-162, 1998.

48. Yu AY, Shimoda LA, Iyer NV, Huso DL, Sun X, McWilliams R, Beaty T, Sham JS, Wiener CM, Sylvester JT and Semenza GL: Impaired physiological responses to chronic hypoxia in mice partially deficient for hypoxia-inducible factor 1alpha. J Clin Invest 103: 691-696, 1999.

49. Semenza GL: Regulation of oxygen homeostasis by hypoxia-inducible factor 1. Physiology (Bethesda) 24: 97-106, 2009. 